\title{
52. ERATOSTHENES SEAMOUNT: AN OCEANOGRAPHIC YARDSTICK RECORDING THE LATE MESOZOIC-TERTIARY GEOLOGICAL HISTORY OF THE EASTERN MEDITERRANEAN ${ }^{1}$
}

\author{
Yossi Mart $^{2}$ and Alastair H.F. Robertson ${ }^{3}$
}

\begin{abstract}
Three boreholes were drilled on the northern slope of the Eratosthenes Seamount during Leg 160. Lithological data were obtained back to the Early Cretaceous. Lithological correlation of shallow-marine sedimentary rocks reveals similarities in the Lower Cretaceous lithological successions of the Eratosthenes Seamount with the southern Levant passive margin. Bathyal chalks of Coniacian-Maastrichtian to middle Eocene age recovered from the Eratosthenes Seamount at Site 967 are also comparable with similar sedimentary units in the Levant. Both the southern margin of the Levant basin and the Eratosthenes Seamount subsided to bathyal depths during Late Cretaceous-Paleogene time. These correlated successions differ from contemporaneous units in southern Cyprus that are dominated by the Upper Cretaceous Troodos ophiolite and its deep-sea sedimentary cover. The presence of shallow-marine limestones of Miocene age on the Eratosthenes Seamount indicates uplift before, or during, the Miocene, whereas the overlying Pliocene-Pleistocene successions comprise unlithified hemipelagic sediments that accumulated in deeper water following tectonic subsidence. Previously obtained geophysical data suggest that the Eratosthenes Seamount has variable crustal characteristics. Seismic refraction data reveal an intermediate crustal layer of seismic velocity of $6.1-6.3 \mathrm{~km} / \mathrm{s}$ beneath the seamount, which also extends under Cyprus, but then wedges out southward under the Levant basin. A large magnetic anomaly that underlies the seamount and its perimeter was previously correlated with the Troodos ophiolite. However, seismic reflection profiles reveal the existence of an important northward-dipping thrust fault separating Cyprus from the Eratosthenes Seamount. Taken together, the geophysical and geological evidence indicate that the tectonic evolution of the Eratosthenes Seamount is linked to that of the North African continental margin from early Mesozoic time onward. The seamount was in a shallow-marine depositional setting in the Early Cretaceous, then subsided to bathyal depths in the Late Cretaceous. It was later uplifted, as indicated by the Miocene shallow-marine limestones recovered from Sites 965 and 966. Then, during Pliocene-Pleistocene time, the Eratosthenes Seamount was thrust beneath Cyprus because of collision of the African and the Eurasian plates.
\end{abstract}

\section{INTRODUCTION}

The Eratosthenes Seamount is a large, submerged massif situated on the seafloor of the Eastern Mediterranean about $100 \mathrm{~km}$ south of Cyprus. It is elliptical in shape, nearly $120 \mathrm{~km}$ long and $80 \mathrm{~km}$ wide, and its major axis is oriented northwest-southeast (Fig. 1). The morphologic relief of this seamount exceeds $2000 \mathrm{~m}$, measured from the peak, at $690 \mathrm{~m}$ depth, to the Eratosthenes Abyssal Plain to the west, at $2700 \mathrm{~m}$ (Hall et al., 1994). The seamount is one of the largest subsurface features on the Eastern Mediterranean seafloor, second only to the regional-scale Mediterranean Ridge and the Hellenic Trench system. Much of the eventful tectonic and oceanographic history of the Eastern Mediterranean Sea is recorded in the sedimentary rocks of the Eratosthenes Seamount, as discussed below.

The first surveys carried out around the seamount were those of the research vessels Vema, Conrad, Chain, and Pillsbury. Emery et al. (1966) and Ryan et al. (1970) reported the results from these cruises. Subsequently, detailed surveys were conducted by the Shikmona (Neev et al., 1976), Shackleton (Woodside and Williams, 1977; Tanner and Williams, 1984), Akademik Nikolaj Strakhov (Krasheninnikov and Hall, 1994), and Galendzhik (Limonov et al., 1994). Data were also obtained by the Marion Dufresne (Murat, 1984; Murat and Got, 1987) and the Bannock (Catani et al., 1983). Additional data were recorded by the research vessels Atlantic Seal, Arctic Seal, Aragonese, Atlantis II, Bayard, Discovery, Salernum, Shoup, Vavilov,

${ }^{1}$ Robertson, A.H.F., Emeis, K.-C., Richter, C., and Camerlenghi, A. (Eds.), 1998. Proc. ODP, Sci. Results, 160: College Station, TX (Ocean Drilling Program).

${ }^{2}$ Leon Recanati Center for Marine Studies, Haifa University, Haifa 31905, Israel. y.mart@research.haifa.ac.il.

${ }^{3}$ Department of Geology and Geophysics, University of Edinburgh, West Mains Road, Edinburgh EH9 3JW, United Kingdom. and also during a series of cruises of the Osservatore de Geofisica Sperimentale, Trieste, Italy and the Institut Français du Petrole (see Hall et al., 1994, for a bibliography). Although much useful information about the bathymetry and physiography of the Eratosthenes Seamount was obtained, none of these expeditions carried out systematic bottom sampling to determine the nature of the sediments and rocks making up the seamount. Piston cores were obtained during the Chain, Cruise 61, and Marion Dufresne, Cruise 82-07, and dredge samples were obtained by the Bannock and the Strakhov. In addition, large-diameter cores were recovered from the crestal and eastern margins of the Eratosthenes Seamount during the Galendzhik sitesurvey cruise before Leg 160 (Limonov et al., 1994; Robertson et al., 1994, 1995b).

Woodside (1977) described the Eratosthenes Seamount as a large anticlinal structure that peaks at a depth of $\sim 700 \mathrm{~m}$. He also recognized subsurface stratification down to a strong seismic reflector, which was traced at a sub-bottom travel time of $0.2-0.5 \mathrm{~s}$. This seismic reflector differs in its signature from the $\mathrm{M}$ reflector that marks the top of the Messinian evaporites in the Mediterranean (Ross and Uchupi, 1977; Mart, 1979). The obvious explanation of the absence of the M reflector is that the seamount was already an elevated feature and thus was not covered by evaporites during the Messinian (Kempler and Ben-Avraham, 1987; Sage et al., 1988; Krasheninnikov et al., 1994; Limonov et al., 1994; Robertson et al., 1995b). Drilling of the Eratosthenes Seamount could clearly provide invaluable information regarding the oceanography and the tectonics of the eastern Mediterranean in pre-Messinian time (McCoy and Mart, 1988; Robertson, 1992)

Woodside (1977) also noted the occurrence of a 200-km-wide magnetic anomaly underneath the seamount. Ben-Avraham et al. (1976) correlated this anomaly with magnetite-rich basic volcanics, similar to those of the Troodos ophiolite, at a depth of $2-4 \mathrm{~km}$ be-

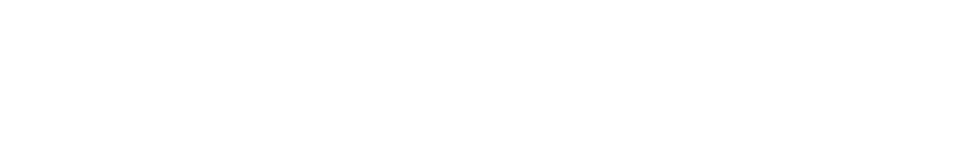




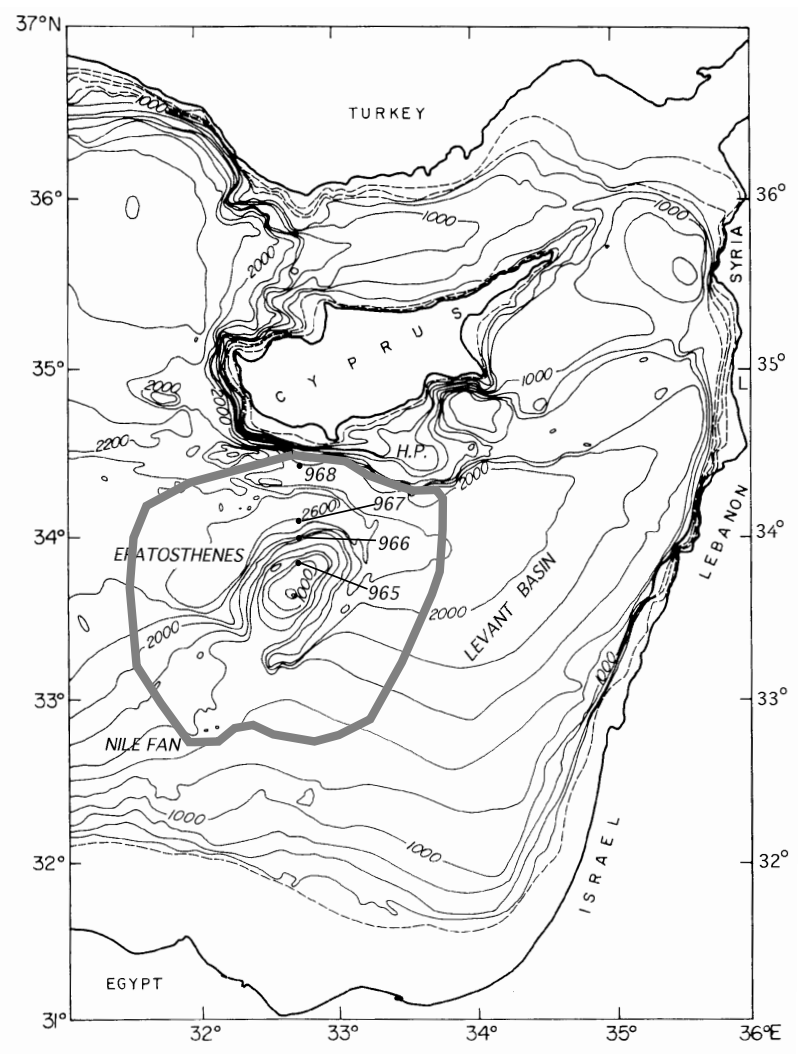

Figure 1. Bathymetric chart of the easternmost Mediterranean Sea (after Hall, 1980), showing the location of Leg 160 sites. Note the bathymetric deeps that surround the seamount.

neath the seafloor. Woodside (1977) also reported a substantial freeair gravimetric anomaly that is not accompanied by a Bouguer anomaly. A seismic refraction profile run between the Eratosthenes Seamount and the Levant Basin later revealed crustal differences between the seamount and the adjacent deep-sea basin, and it pointed out a similarity of crustal structure between the seamount and Cyprus (Makris et al., 1983). The seismic results were generally held to oppose the existence of a plate boundary between Eratosthenes Seamount and Cyprus.

The detailed site survey for Leg 160 was performed by the Galendzhik during the summer of 1993 (Limonov et al., 1994; Robertson et al., 1994, 1995a). The high-quality data seismic data obtained during this cruise confirmed the validity of the original Ocean Drilling Program (ODP) proposal to drill a north-south transect of holes across the Eratosthenes Seamount as far as the Cyprus slope, and the data allowed individual sites to be positioned most favorably. In addition, the Galendzhik cruise provided improved seismic resolution of the subsurface structure of the Eratosthenes Seamount, especially of the northern and southern margins, and also documented largescale normal faulting and sediment instability along the eastern margin.

During April 1995, a transect of four holes was drilled by the JOIDES Resolution over a period of nearly three weeks. The transect extended from the northern plateau of the seamount, across the upper and lower slopes of the seamount, to the lower slopes of the Cyprus margin (Emeis, Robertson, Richter, et al., 1996). The intervening deep basin was not drilled because it contains thick, unconsolidated, Pliocene-Pleistocene sediments that would have yielded little relevant information.
A remarkable and unexpected achievement of Leg 160 was that Cretaceous units were reached in one hole at Site 967 (Fig. 2; Emeis, Robertson, Richter, et al., 1996). Hole 967E was drilled to a depth of $600 \mathrm{mbsf}$ on the lower northern slope of the seamount at a water depth of $2500 \mathrm{~m}$. The succession recorded begins with nearly $100 \mathrm{~m}$ of Pliocene-Pleistocene hemipelagic sediments, including sapropels, and is followed by around $25 \mathrm{~m}$ of uppermost Miocene-lower Pliocene micritic and recrystallized carbonates. The presence of gypsum was inferred from borehole geophysical evidence. Bathyal pelagic chalks were recovered, first of lower Oligocene, and then of Maastrichtian-Cenomanian age (Premoli-Silva et al., Chap. 30, this volume; Robertson, Chap. 51, this volume). Finally, the bit penetrated $154 \mathrm{~m}$ of carbonates that record shallow-water sedimentation that ended in the late Aptian (Premoli-Silva et al., Chap. 30, this volume; Fig. 2). The successions recovered from Sites 965 and 966, elsewhere on the Eratosthenes Seamount (Fig. 3), include Pliocene-Pleistocene hemipelagic sediments, which overlie Messinian nonmarine carbonates at Site 965 (Böttcher et al., Chap. 29, this volume), Miocene shallow-marine limestones at Sites 965 and 966, and pelagic carbonates of middle Eocene age at Site 967 (Emeis, Robertson, Richter, et al., 1996). Significantly absent from all the Eratosthenes boreholes is any evidence for volcanic activity of any age. Detailed petrological and X-ray diffraction studies have revealed that a minor lithogenic component is present throughout the sedimentary successions of the Eratosthenes Seamount, but this is of terrigenous origin (Robertson, Chap. 51, this volume).

\section{STRUCTURE OF ERATOSTHENES SEAMOUNT}

The upper part of the Eratosthenes Seamount, above the $1100 \mathrm{~m}$ isobath, is divided into northern and southern level summit areas by prominent fault-controlled declivities, extending as far as the eastern and western flanks (Krasheninnikov et al., 1994; Limonov et al., 1994). The crest of the southern summit is at $690 \mathrm{~m}$, whereas a subsidiary, northern summit is located at greater depth, above a steeper slope. The northern and eastern slopes are segmented by a series of normal faults, associated with sediment instability including slumping (Limonov et al., 1994; Robertson et al., 1994, 1995b). Sedimentfilled basins also surround the margins of the seamount. These vary in depth from $1500 \mathrm{~m}$ to the south, in the bathymetric saddle between the seamount and the Nile deep-sea fan, to $2700 \mathrm{~m}$ to the northwest, where the lower slope of the seamount merges with a small Eratosthenes Abyssal Plain (Emery et al., 1966; Woodside and Williams, 1977). A large, northward-dipping fault exists between the Eratosthenes Seamount and Cyprus (Woodside, 1977). This fault has been widely interpreted as a northward-dipping thrust fault (Rotstein and Kafka, 1982; Kempler and Ben-Avraham, 1987; Kogan and Stenin, 1994; Limonov et al., 1994; Robertson et al., 1994, 1995a). Several authors have suggested a lateral (i.e., strike-slip) component to movement along this fault, but without definite evidence (Giermann, 1969; Ben-Avraham et al., 1976; Kempler and Ben-Avraham, 1987; Kempler, 1994).

Before Leg 160, the crest and slopes of the Eratosthenes Seamount were known to be composed of Pliocene-Pleistocene hemipelagic muds (Murat, 1984; Murat and Got, 1987), but the pre-Pliocene stratigraphy was unknown. During dredging of the western slopes of the Eratosthenes Seamount by the Strakhov, three rock samples were retrieved and identified as granite, basalt, and chalk. Krasheninnikov et al. (1994) suggested that the granite came from a seafloor exposure of Precambrian crystalline rocks of the Afro-Arabian platform. These were exposed on the seafloor "as a result of destructive deformations with huge vertical amplitude" (Krasheninnikov, 1994, p. 128). These authors also suggested that the basaltic clast was derived from an ophiolite underlying the floor of the Levantine Sea. This ophiolite 


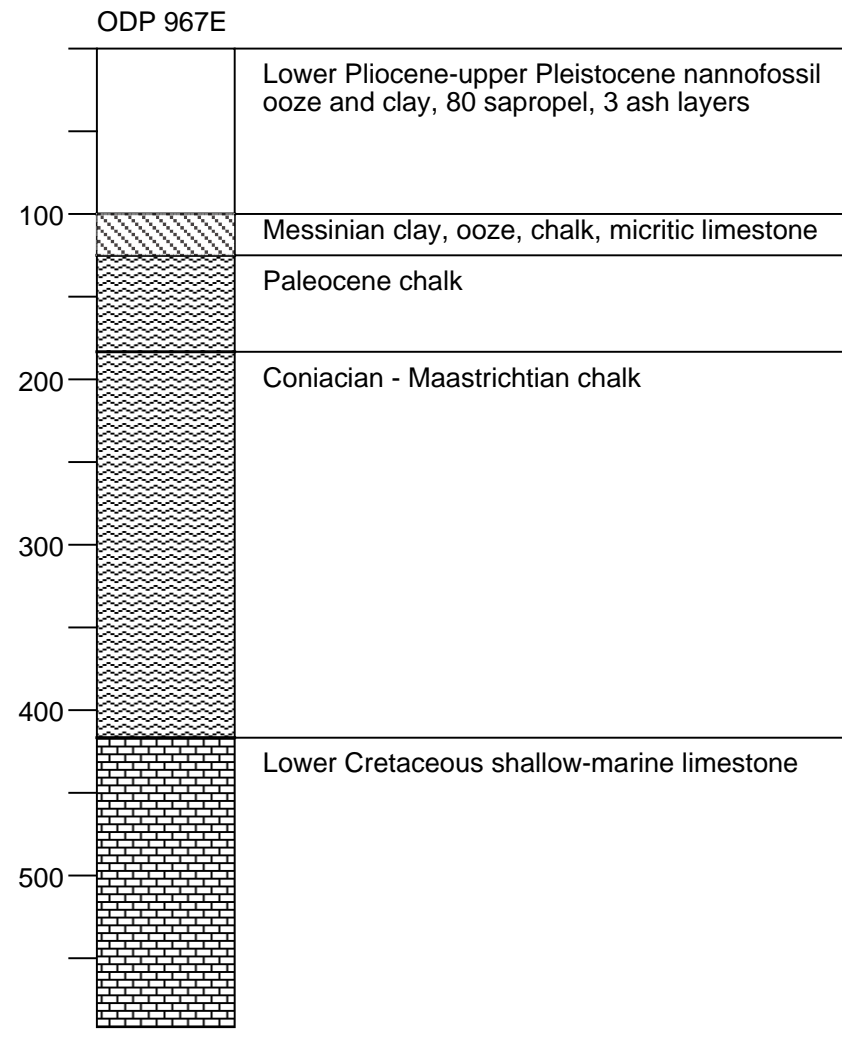

Figure 2. Stratigraphic log of borehole at Hole 967E, on the northern slope of the Eratosthenes Seamount.

was later uplifted and exposed on the seafloor floor together with rocks of the Eratosthenes Seamount. However, the granite and basalt clasts are only $\sim 3 \mathrm{~cm}$ across and are rounded and unweathered. These clasts are very unlikely to have been derived from in situ submarine outcrops. Considering the intensive maritime transportation of igneous rocks from Egypt to Rome and Greece that existed in ancient times, as well as the size, shape, and state of alteration of the dredged clasts, we interpret them as anthropogenic dropstones, a possibility that is acknowledged by Krasheninnikov et al. (1994).

By contrast, the dredged chalk sample is a orthogonal fragment, measuring $40 \times 30 \times 15 \mathrm{~cm}$. Three of its surfaces are freshly broken, exposing white chalk, whereas the other three are covered by a crust of very dark limestone, enriched with iron or manganese oxides. Krasheninnikov et al. (1994) suggested that the chalk was possibly of mid-Cretaceous age, based on its lithological similarity with carbonate rocks in Syria. However, in spite of intensive recrystallization, Z. Lewy and G. Martinotti (pers. comm., 1992) observed faunal evidence in the chalk that suggests a Miocene age. Core samples studied from Sites 965 and 966 show very similar lithological compositions (Robertson, Chap. 33, this volume). Also, foraminifers in the dark calcareous crust of the dredged chalk sample are indicative of a late Miocene age (G. Martinotti, pers. comm., 1992; Krasheninnikov et al., 1994). Evidence for manganese-rich sediments on the crest of Eratosthenes Seamount was also reported by Varnavas et al. (1988), who suggested a hydrothermal origin for these sediments, although, until now, no specific magmatic source has been identified. Alternatively, these metal enrichments could all be of hydrogenous origin, unrelated to volcanism.

The lithologies beneath the sedimentary succession drilled during Leg 160 remain unknown (i.e., pre-Early Cretaceous). However, the

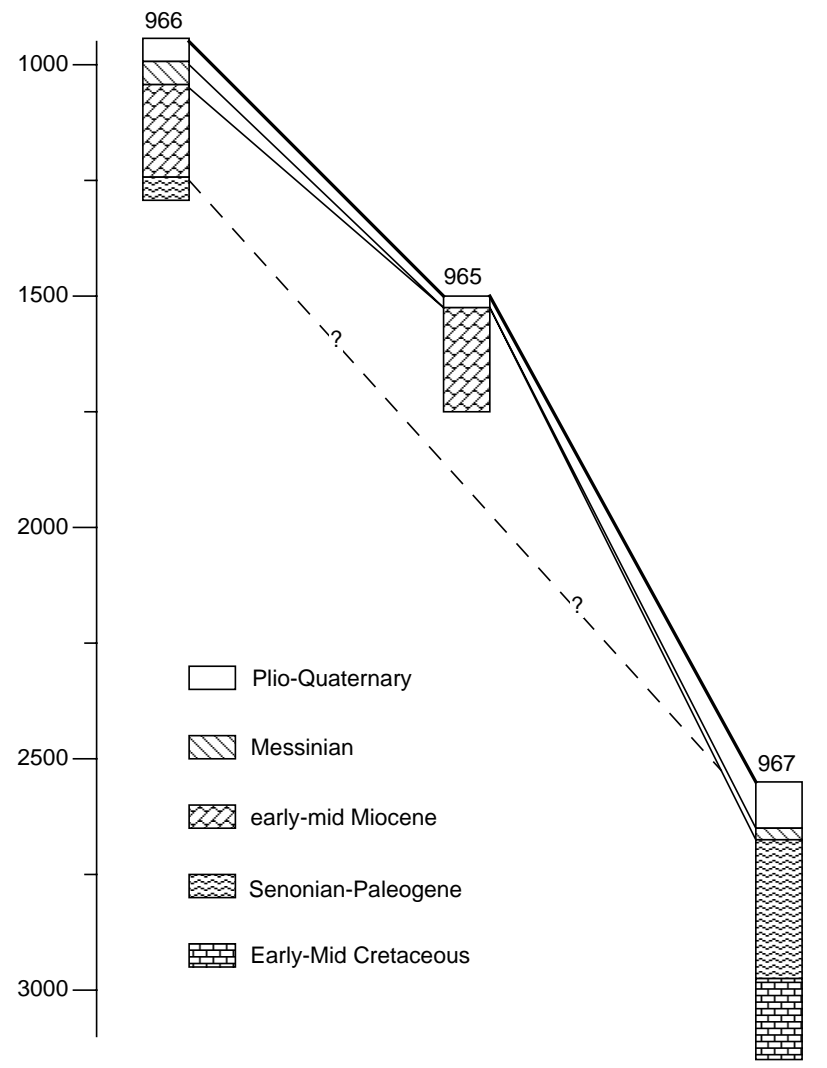

Figure 3. Stratigraphic section across the northern margin of Eratosthenes Seamount, showing the lithostratigraphy recovered at Sites 965, 966, and 967.

evidence of the large elliptical magnetic anomaly, nearly $200 \mathrm{~km}$ across, which underlies the seamount (Woodside, 1977; Makris and Wang, 1994), suggests the occurrence of a magnetite-rich lithology at a depth of 2-4 km beneath the seafloor, presumably mafic or ultramafic rock (Ben-Avraham et al., 1976). Consequently, Ben-Avraham et al. (1976) suggested a genetic association between the Eratosthenes Seamount and the Troodos ophiolite. However, basalts beneath the seamount, if present, could also be associated with Lower Jurassic or Lower Cretaceous volcanics known from the southern Levant. Also, Upper Triassic and Upper Cretaceous basalts are present in southern Cyprus (see below). Seismic refraction data show that the crustal structure of the Eratosthenes Seamount is characterized by a seismic velocity layer of $6.0-6.3 \mathrm{~km} / \mathrm{s}$, at intermediate crustal depths (i.e., 15-20 km), and velocities in the lower crust are measured as 6.7 $\mathrm{km} / \mathrm{s}$ (Makris et al., 1983; Makris and Wang, 1994). Combining the magnetic, gravity, and seismic refraction data, the most reasonable interpretation is that the seamount is underlain by thinned continental crust, about $25-27 \mathrm{~km}$ thick, associated with mafic or ultramafic bodies, possibly related to rifting.

\section{TECTONIC SETTING OF THE LEVANT BASIN IN RELATION TO ERATOSTHENES}

The Levant Basin lies in the southeastern part of the Mediterranean Sea. It comprises a gently dipping continental rise that deepens northwestward from the base of the continental slope of the southern Levant and Sinai at depths of 1000-1200 m, to reach depths of 2200- 
$2300 \mathrm{~m}$ in the trough between the Eratosthenes Seamount and Cyprus (Fig. 1). The Levant Basin is bounded by the northeastern African continental margin to the south and by the southern Levant continental margin to the southeast. Its northern boundary is the continental margin of Cyprus and the Hecataeus-Latakia structural lineament (Kempler, 1994), and its western boundary comprises the Nile deepsea fan and the Eratosthenes Seamount.

Seismic refraction surveys and gravimetric measurements suggest that sediments more than $12 \mathrm{~km}$ thick are present beneath the Levant Basin (Ginzburg and Gvirtzman, 1979; Makris and Wang, 1994). These geophysical data also reveal a high-velocity layer $(6.7 \mathrm{~km} / \mathrm{s})$ beneath the sediments, and the presence of the Moho at a depth of $22-25 \mathrm{~km}$. These crustal properties of the basinal area differ from those of the margins of the Levant Basin, specifically beneath the Eratosthenes Seamount to the west and the Levant margin to the east. In these marginal areas, an intermediate crustal layer with a seismic velocity of about $6.0 \mathrm{~km} / \mathrm{s}$ and a density of about $2.85 \mathrm{~g} / \mathrm{cm}^{3}$ is inferred to exist.

Geological evidence from the Eastern Mediterranean Sea region indicates the existence of deep-marine basins in this area at least since the Triassic (Smith, 1971; Dewey et al., 1973; Ryan, Hsü, et al., 1973; Robertson and Dixon, 1984; Dercourt et al., 1986, 1993). Some view this basin as essentially an intracontinental rift (Hirsch and Picard, 1988), whereas others have presented regional geological evidence of mafic volcanism and deep-sea sedimentation, which could indicate seafloor spreading by Late Triassic time (Robertson and Woodcock, 1980; Garfunkel and Derin, 1984). The tectonic evolution of the easternmost Mediterranean area is discussed in detail elsewhere in this volume (Robertson et al., Chap. 54, this volume). In general, the continental margin of northeast Africa is widely interpreted as a passive margin adjacent to a Mesozoic oceanic basin (Smith, 1971; Dewey et al., 1973). Some authors have interpreted the Levant margin as an early Mesozoic transform margin segment (Dewey et al., 1973; Robertson and Dixon, 1984; Şengör et al., 1984), whereas Garfunkel and Derin (1984) favor a rifted divergent margin origin.

\section{CRETACEOUS-TERTIARY SETTING OF THE SOUTHERN LEVANT}

The southern Levant underwent several phases of uplift, deformation, and erosion that have affected the stratigraphic record, particularly giving rise to stratigraphic hiatuses. Major erosional episodes occurred in the Permian, Triassic, Early Jurassic, Early Cretaceous (Weissbrod, 1981; Garfunkel and Derin, 1984; Garfunkel, 1991), late Oligocene, and Pleistocene (Gvirtzman, 1970; Horowitz, 1979; Mart, 1987). Shallow-marine sedimentary rocks, including limestones, dolomites, marls, sandstones, and local evaporites, dominate the Mesozoic sequence. Sedimentological evidence from outcrops and exploration boreholes drilled in the continental margin and the coastal plain, reveal a trend of northwestward deepening of the marine environment (Bein and Gvirtzman, 1977). Seismic reflection surveys across the distal continental margin indicate shelf and proximal slope depositional environments for Early to mid-Cretaceous time (Mart, 1994). Lithological and paleontological evidence from the southern Levant indicates a depositional change from neritic limestone to pelagic-hemipelagic chalk deposition during Coniacian-Santonian time. This change was possibly related to abrupt tectonic subsidence to form an open marine basin that remained until the middle Eocene (Mart, 1991; 1994). In addition, Late Cretaceous eustatic sea-level change played a part in this transgression. The Campanian succession in the southern Levant is particularly rich in phosphorite and chert; phosphate deposits also occur in other Upper Cretaceous and Eocene units. Paleoceanographic evidence indicates that upwelling along the proximal Levant continental margin was associated with a strong increase in biological productivity, which led to deposition of phosphorites, initially in Late Cretaceous time (Almogi-Labin et al., 1993).
Westward thickening of the inferred Late Cretaceous seismic interval supports an interpretation that the upwelling was somehow related to subsidence of the Levant basin to the west (Mart, 1994).

The Late Mesozoic-Early Cenozoic structure of the southern Levant is controlled by a series of asymmetric anticlines and synclines. These deformed units form an elongate structural zone, about 1000 $\mathrm{km}$ long and $150 \mathrm{~km}$ wide, dominated by folding and reverse faulting. This zone extends from northern Sinai to southern Syria, and is known as the "Syrian Arc". A typical individual anticline is about $100 \mathrm{~km}$ long and $30 \mathrm{~km}$ wide, with an original structural relief of 1000-2500 m. The Syrian Arc is interpreted as the result of regional tectonic compression that took place in the late Turonian (Picard, 1943). The folding had the effect of inverting pre-existing normal faults, so that anticlines overlie high-angle reverse faults (Freund et al., 1975; Cohen et al., 1990). Freund et al. (1975) suggested that the inversion of the Syrian Arc reactivated normal faults of Late Jurassic-Early Cretaceous age, whereas Garfunkel and Derin (1984) argued that the related extensional faulting was of Late Triassic-Early Jurassic age. Volcanism is known to have occurred in the southern Levant, both during the Early Jurassic and the Early Cretaceous (Steinitz et al., 1982; Laws and Wilson, 1996). Freund et al. (1975) linked a southward increase of the $\mathrm{K}_{2} \mathrm{O} / \mathrm{SiO}_{2}$ ratio in the Lower Cretaceous volcanic rocks with a tectonic model, involving southward subduction from the Tethyan Ocean to the north. However, this model has since fallen out of favor (e.g., Bonen, 1980), mainly because interpretation of the tectonic setting of extrusive igneous rocks based on major-element composition (i.e., subject to chemical mobility) is no longer considered reliable. Garfunkel (1991) argues instead that the Lower Cretaceous volcanics are of hot-spot type. More recently, detailed trace element and rare earth element (REE) geochemical studies of basalt samples from outcrops and wells from Israel and adjacent areas indicate that their composition is consistent with either a rift or hot-spot origin (Laws and Wilson, 1996).

\section{SOUTHERN CYPRUS DURING THE CRETACEOUS}

The Cretaceous history of southern Cyprus was dominated by the genesis of the Troodos ophiolite at about 92-88 Ma, based on radiometric dating of plagiogranite (Musaka and Ludden, 1987). Geochemical evidence indicates that the ophiolite formed by crustal accretion processes above a subduction zone (Pearce et al., 1984). Recent work has provided no support for an earlier concept of the ophiolite as a grossly allochthonous thrust sheet derived from far to the north as central Turkey or beyond. Most workers now believe that the ophiolite formed, and has remained, in the southern Neotethys, near its present position in the eastern Mediterranean (Robertson and Xenophontos, 1994). Notably, the Upper Cretaceous metalliferous and pelagic sedimentary cover of the Troodos ophiolite is tectonically undisturbed in many areas, and there is no evidence of uplift or exposure that could reflect regional thrust emplacement during Late Mesozoic-Early Tertiary time (Robertson, 1990). During the Late Cretaceous, the Troodos ophiolite docked with a contrasting lithotectonic terrain, the Mamonia Complex of western Cyprus. Two tectonically related units; the lower, mainly igneous, Dhiarizos Group of mainly Triassic age, and the entirely sedimentary Ayios Photios Group of Late Triassic-Early Cretaceous age dominate the Mamonia Complex (Lapierre, 1975; Swarbrick and Robertson, 1980). These two units are reconstructed as a Mesozoic Neotethyan passive continental margin (Robertson and Woodcock, 1980). The sedimentary Ayios Photios Group represents mid to lower slope and abyssal plain settings of a small Neotethyan oceanic basin, whereas the volcanics of the Dhiarizos Group represent remains of Late Triassic peripheral (near continental margin) oceanic crust. It was initially believed that the Triassic volcanics are all of alkaline chemical type, consistent with a rift or oceanic island setting (Lapierre, 1975; Robertson and Woodcock, 1980). However, recently, MORB-type basalts were recognized (Malpas et al., 1992), and these, together with associated 
bathyal radiolarite and Triassic pelagic limestone, are indicative of an oceanic crustal origin (Robertson, 1990). A conclusion that is also supported by evidence from southern Turkey (Robertson, Chap. 54, this volume) is that oceanic crust formed in the easternmost Mediterranean by Late Triassic (Carnian-Norian) time.

After genesis above an inferred subduction zone, the Troodos ophiolite was depositionally overlain by metalliferous sediments ("umbers") that, in turn, pass upward into radiolarites and volcanogenic sediments of Campanian age (Perapedhi and Kannaviou Formations). Overlying these sediments are pelagic chalks of Maastrichtian to late Oligocene age (Lefkara Formation). During the Miocene, various shallow- to deeper water carbonate sediments accumulated (Pakhna Formation), as summarized in Robertson et al. (1991). Gypsum was precipitated during the Messinian, followed by accumulation of marine argillaceous to calcareous sediments in the early-late Pliocene (Nicosia and Athalassa Formations), and finally, nonmarine clastics and coastal deposits in the Pleistocene (Poole et al., 1990; Poole and Robertson, Chap. 43, this volume).

The lithological succession of southern Cyprus contrasts strongly with that of the Eratosthenes Seamount at Hole 967E and with the southern Levant. Notably, evidence of ophiolite formation and tectonic deformation, as recorded in western Cyprus, are absent from the Eratosthenes Seamount, where there are no Upper Cretaceous radiolarian deposits or evidence of ophiolite emplacement, such as collapse related to crustal loading. Pelagic carbonates are indeed present in both areas, but the age and facies are different (Premoli-Silva et al., Chap. 30, this volume; Robertson, Chap. 32, this volume). Deposition between the Maastrichtian and the late Oligocene was largely continuous in southern Cyprus, whereas several hiatuses and periods of reworking are recorded on the Eratosthenes Seamount (PremoliSilva et al., Chap. 30, this volume; Flecker et al., Chap. 40, this volume).

\section{DISCUSSION: PLATE TECTONIC SETTING}

The precise location of the plate boundary between Cyprus and the Levant had long been disputed. Suggestions as to its location have included topographic lineaments within Cyprus (e.g., McKenzie, 1970; North, 1974), between Cyprus and the Eratosthenes Seamount (Dewey et al., 1973; Biju-Duval et al., 1977; Şengör et al., 1984; Dercourt et al., 1986, 1993). Even a location to the south of the seamount was suggested (Ross and Uchupi, 1977). Some have even doubted whether any plate boundary actually exists near the Eratosthenes Sea- mount, preferring to regard the Eratosthenes Seamount simply as an uplifted part of the regionally extensive North African continental margin (Malovitsky et al., 1975; Neev et al., 1976, 1985; Hirsch, 1984; Hirsch et al., 1995).

If a boundary between the African and Eurasian Plates does not in fact exist between Cyprus and the Eratosthenes Seamount, then the sedimentary successions of both areas would be expected to be similar. However, drilling at Site 967 showed that the Late Cretaceous and early Tertiary history of southern Cyprus does indeed differ markedly from that of Eratosthenes (Emeis, Robertson, Richter, et al., 1996; Robertson et al., 1995a; Chap. 54, this volume). Noticeably absent from Eratosthenes Seamount is any evidence of ophiolitic or other volcanogenic lithologies, unlike southern Cyprus. By contrast, the Cretaceous and lower Tertiary sedimentary successions of the seamount are similar to those of the southern Levant. Notably, shallow-marine carbonates of Early Cretaceous age are overlain by Senonian, Paleocene, and Eocene chalks in both areas (Fig. 4). The Eratosthenes Seamount is therefore assumed to be linked with the African Plate in contrast to southern Cyprus, which relates to the formation and destruction of a Neotethyan oceanic basin further north.

The regional arcuate chain of ophiolites, which extends from Cyprus to Oman, is widely held to be related to Late Cretaceous subduction of a southern Neotethyan oceanic basin (e.g., Moores et al., 1984; Pearce et al., 1984; Robertson and Dixon, 1984). Alternatively, some workers favor a mid-ocean ridge origin (e.g., Gass, 1968; Whitechurch et al., 1984). One widespread view is that ophiolites such as the Troodos formed during the initial stages of intra-oceanic subduction, before genesis of a well-established volcanic arc (e.g., Pearce et al., 1984; Robertson, 1990; Malpas et al., 1990). Accepting that subduction played an important role, an immediate question is whether a single or several subduction zones dipped northward or southward at different times in the easternmost Mediterranean region.

\section{Northward Subduction Models}

Subduction toward the north and northeast within the southerly Neotethyan ocean is widely assumed on regional grounds (i.e., from the Eastern Mediterranean to Oman and the Himalayas; Moores et al., 1984; Pearce et al., 1984; Robertson and Dixon, 1984). The main reason is that the ophiolites were emplaced over generally northward-
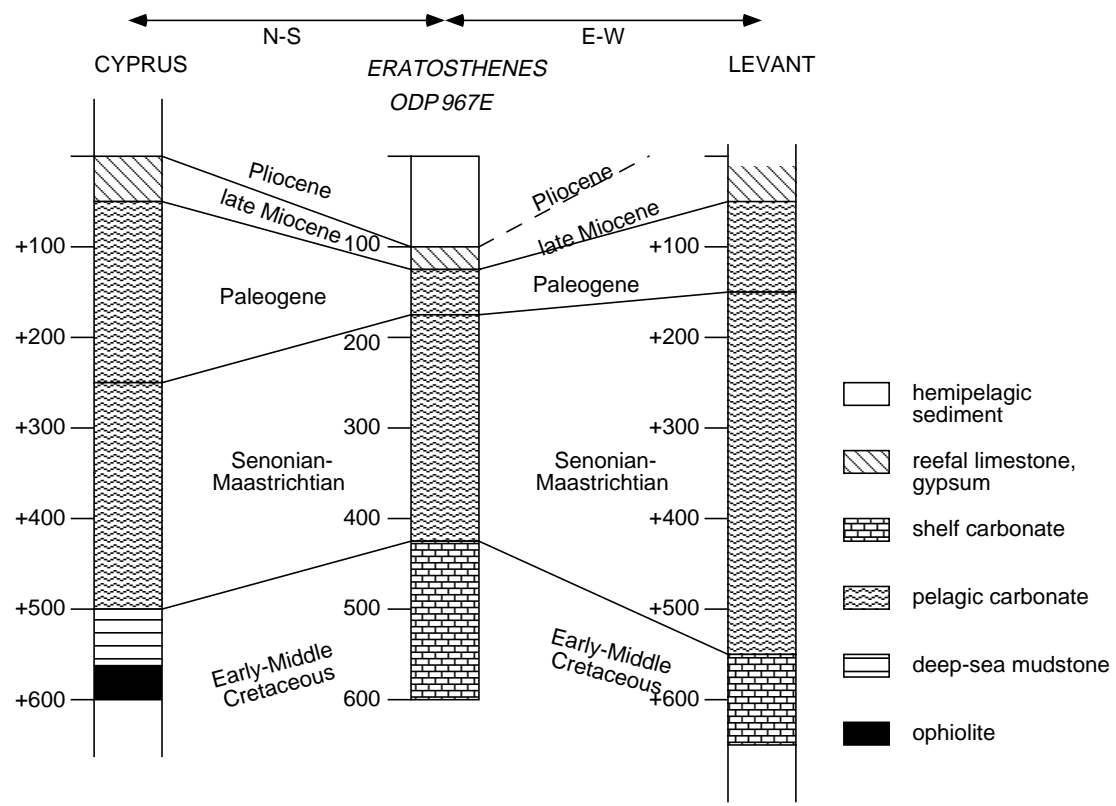

Figure 4. Correlation of Hole 967 with composite stratigraphic sections of southern Cyprus and northwestern Israel. See text for reference to literature sources. 
dipping thrust belts inferred to represent subduction-accretion complexes generated by northerly rather than southerly subduction (e.g., in Oman). Also, the metamorphic soles of the regionally obducted ophiolites (excluding the Troodos ophiolite) show evidence of southerly displacement (e.g., in Syria and Oman). These soles are thought to represent the emplaced leading edges of generally northwarddipping oceanic subduction zones (e.g., Searle and Malpas, 1982).

One speculative option is that the present northward-dipping thrust fault separating Eratosthenes Seamount from Cyprus could represent the reactivation of an earlier, Late Cretaceous subduction zone related to genesis of the Troodos ophiolite. Such a subduction zone could have been dormant in the early Tertiary, but then reactivated in the Neogene, related to the later stages of consumption of the southerly Neotethys in the easternmost Mediterranean area. By Neogene time, the remaining Neotethyan ocean crust to the north, in the Turkish area, was completely consumed and the continuing convergence of the African and Eurasian Plates was taken up south of Cyprus, activating a complex subduction zone between Cyprus and the Eratosthenes Seamount (Robertson, 1990; Kempler, 1994).

\section{Southward Subduction Models}

Dilek et al. (1990) suggested that a subduction zone dipped southward from central southern Turkey, creating the Troodos as a backarc basin along the northern margin of Gondwana. An obvious problem, however, with this model is the absence of a related magmatic arc of the appropriate age (i.e., mid-early Late Cretaceous). Also, any interpretations of spreading or subduction polarity must take into account the well-known counterclockwise paleorotation of the Troodos ophiolite (Moores and Vine, 1971), that occurred from Late Cretaceous through early Eocene time (Clube and Robertson, 1986; Morris, 1995). The occurrence of a southward-dipping Neotethyan subduction zone in the easternmost Mediterranean area was also suggested by Freund et al. (1975), but was not supported by later work, as pointed out earlier. In addition, Hsü (1992) suggested the existence of a southward-dipping subduction zone between Cyprus and Eratosthenes Seamount during the Miocene. He suggested that the seamount now overlies a frontal island arc, and compared the eastern Mediterranean to the eastern Alps in the Tertiary (Closs, 1975) and to the South China Sea at present. However, no supporting evidence for this tectonic model was found during Leg 160, as magmatic rocks were not recovered and interpretation of seismic reflection profiles suggests that the present tectonic boundary between the Eratosthenes Seamount and Cyprus is a northward-dipping thrust.

\section{Neogene-Holocene North-Dipping Subduction}

The existence of a presently north-dipping subduction between Cyprus and Eratosthenes Seamount is supported by the regional seismicity (Rotstein and Kafka, 1982), seismic reflection data (Krasheninnikov et al., 1994; Limonov et al., 1994), and geological evidence from Leg 160, and by the on-land geology of Cyprus and the Levant. However, the existence of this subduction zone is far from obvious if only seismic refraction data are considered. According to this evidence, the composition of the crust beneath both Cyprus and the Eratosthenes Seamount is similar (Makris et al., 1983; 1994; Makris and Wang, 1994). A tectonic model proposed by Leg 160 Scientific Party (Robertson et al., 1995a) implies that in the past the Eratosthenes Seamount was separated from Cyprus by Neotethyan oceanic crust that was subducted northward in Neogene-Holocene time. The section of the oceanic crust that underlies the Levant Basin (Makris and Wang, 1994) is probably a relict of the same oceanic basin. The tectonic evolution of this oceanic basin was associated with volcanism and rifting that affected the southern Levant during the Early Jurassic, Early Cretaceous, or both (Freund et al., 1975; Robertson and Dixon, 1984; Garfunkel, 1991; Dercourt et al., 1993). Er- atosthenes Seamount is thus an integral part of a paleo-Levantine oceanic basin. Associated with Africa-Eurasia plate convergence, northward subduction of Mesozoic oceanic crust remaining within the Levant basin during Neogene-Holocene time culminated in collision of the Eratosthenes Seamount, attached to the African Plate, with Cyprus, representing the leading edge of the Eurasian Plate. In general terms, the collision of the North African continental margin with Cyprus has long been seen as a cause of uplift of the island (Gass and Masson-Smith, 1963). The discovery that the Eratosthenes Seamount is not associated with a Bouguer gravimetric anomaly suggests that the seamount is not isostatically compensated at depth, but is dynamically supported as a result of collision (Robertson et al., 1994, 1995b; Mart et al., 1997). Indeed, the inferred tectonic emplacement of the Troodos ophiolite onto the Eratosthenes Seamount records a rare example of present-day obduction, in which oceanic crust is thrust over continental crust. In summary, although the seismic refraction evidence (Makris et al., 1983) can be interpreted to indicate that continental crust is continuous between Eratosthenes and Cyprus, this has probably resulted from collision and superposition of crustal units south of Cyprus (i.e., Cyprus active margin), thus obscuring potential seismic refraction evidence of this plate boundary.

\section{CONCLUSIONS}

The results of drilling the Eratosthenes Seamount during Leg 160, combined with site-survey geophysical data, are consistent with a setting of the Eratosthenes Seamount as part of the divergent continental margin of North Africa during Mesozoic-early Tertiary time. After shallow-water deposition in the Early Cretaceous, the seamount was submerged in the Late Cretaceous, during genesis of the Troodos ophiolite within the southerly Neotethys adjacent to Gondwana. The seamount remained submerged during the Maastrichtian and Paleogene, but was uplifted by the Miocene. The Eratosthenes Seamount was emergent during the Mediterranean Messinian desiccation crisis. During the Neogene-Pleistocene, oceanic crust of the Levant Basin was subducted northward along a plate boundary located between Cyprus and the Eratosthenes Seamount. The Eratosthenes Seamount underwent intensive faulting and subsidence as a result of incipient collision with Cyprus during the Pliocene-Pleistocene. The collision was also associated with uplift of southern Cyprus. This combined process of subsidence and uplift juxtaposing the continental marginrelated Eratosthenes Seamount unit with the oceanic lithosphere of Cyprus is considered an exceptional example of incipient ophiolite obduction (Robertson et al., 1995a, 1995b; Mart et al., 1997).

\section{ACKNOWLEDGMENTS}

We are grateful to Jean Mascle, Phyllis M. Garman, and an anonymous reviewer for their constructive reviews of the initial version of this paper.

\section{REFERENCES}

Almogi-Labin, A., Bein, A., and Sass, E., 1993. Late Cretaceous upwelling system along the southern Tethys margin, Israel: interrelationship between productivity, bottom water environments, and organic matter preservation. Paleoceanography, 8:671-690.

Bein, A., and Gvirtzman, G., 1977. A Mesozoic fossil edge of the Arabian plate along the Levant coastline and its bearing on the evolution of the Eastern Mediterranean. In Biju-Duval, B., and Montadert, L. (Eds.), Structural History of the Mediterranean Basins: Paris (Editions Technip), 95-109.

Ben-Avraham, Z., Shoham, Y., and Ginzburg, A., 1976. Magnetic anomalies in the eastern Mediterranean and the tectonic setting of the Eratosthenes Seamount. Geophys. J. R. Astron. Soc., 45:105-123. 
Biju-Duval, B., Dercourt, J., and le Pichon, X., 1977. From the Tethys ocean to the Mediterranean Sea: a plate tectonic model of the evolution of the western Alpine system. In Biju-Duval, B., and Montadert, L. (Eds.), Structural History of the Mediterranean Basins: Paris (Editions Technip), 143-164.

Bonen, D., 1980, The Mesozoic basalts of Israel [Ph.D. thesis]. Hebrew Univ. of Jerusalem. (in Hebrew, English abstr.)

Catani, G., Lenardo, G., Marchetti, A., Tunis, G., and Vinci, A., 1983. Sedimentological and seismic features in the Cyprean sector of the eastern Mediterranean Sea: preliminary results. Boll. Oceanol. Teor. Appl., $1: 311-318$

Closs, H., 1975. A subduction model for the Alps derived from Geophysical results. Rapp. Proc. Verb. Comm. Int. Expl. Mer Medit., 23:55-57.

Clube, T.M.M., and Robertson, A.H.F., 1986. The paleoration of the Troodos microplate, Cyprus in the Late Mesozoic-Early Cenozoic plate tectonic framework of the Eastern Mediterranean. Surv. Geophys., 8:375-437.

Cohen, Z., Flexer, A., and Kaptsan, V., 1990. The tectonic mosaic of the southern Levant: implications for hydrocarbon prospects. J. Pet. Geol., 13:437-462.

Dercourt, J., Ricou, L.F., and Vrielynck, B. (Eds.), 1993. Atlas of Tethys Palaeoenvironmental Maps: Paris (Gauthier-Villars).

Dercourt, J., Zonenshain, L.P., Ricou, L.E., Kazmin, V.G., Le Pichon, X., Knipper, A.L., Grandjacquet, C., Sbortshikov, I.M., Geyssant, J., Lepvrier, C., Pechersky, D.H., Boulin, J., Sibuet, J.C., Savostin, L.A., Sorokhtin, O., Westphal, M., Bazhenov, M.L., Lauer, J.P., and BijuDuval, B., 1986. Geological evolution of the Tethys belt from the Atlantic to the Pamirs since the Lias. Tectonophysics, 123:241-315.

Dewey, J.F., Pitman, W.C., Ryan, W.B.F., and Bonin, J., 1973. Plate tectonics and the evolution of the Alpine system. Geol. Soc. Am. Bull., 84:31373180.

Dilek, Y., Thy, P., Moores, E.M., and Ramsden, T.W., 1990. Tectonic evolution of the Troodos ophiolite within the Tethyan framework. Tectonics, 11:954-970.

Emeis, K.-C., Robertson, A.H.F., Richter, C., et al., 1996. Proc. ODP, Init. Repts., 160: College Station, TX (Ocean Drilling Program).

Emery, K.O., Heezen, B.C., and Allan, T.D., 1966. Bathymetry of the eastern Mediterranean Sea. Deep-Sea Res., 13:173-192.

Freund, R., Goldberg, M., Weissbrod, T., Druckman, Y., and Derin, B., 1975. The Triassic Jurassic structure of Israel and its relation to the origin of the eastern Mediterranean. Geol. Surv. Isr. Bull., 65:1-26.

Garfunkel, Z., 1991. Darfur-Levant array of volcanics: a 140-Ma-long record of a hot spot beneath the African-Arabian continent, and its bearing on Africa's absolute motion. Isr. J. Earth Sci., 40:135-150.

Garfunkel, Z., and Derin, B., 1984. Permian-early Mesozoic tectonism and continental margin formation in Israel and its implications for the history of the Eastern Mediterranean. In Dixon, J.E., and Robertson, A.H.F. (Eds.), The Geological Evolution of the Eastern Mediterranean. Geol. Soc. Spec. Publ. London, 17:187-201.

Gass, I.G., 1968. Is the Troodos Massif, Cyprus, a fragment of Mesozoic ocean floor? Nature, 220:39-42.

Gass, I.G., and Masson-Smith, D., 1963. The geology and gravity anomalies of the Troodos Massif, Cyprus. Phil. Trans. R. Soc. London A, 255:417467.

Giermann, G., 1969. The Eastern Mediterranean Ridge. Rapp. Comm. Int. Mer Medit., 19:605-607.

Ginzburg, A., Ben-Avraham, Z., Makris, J., Hubral, P., and Rotstein, Y., 1994. Crustal structure of northern Israel. Mar. Pet. Geol., 11:501-506.

Ginzburg, A., and Gvirtzman, G., 1979. Changes in the crust and in the sedimentary cover across the transition from the Arabian platform to the Mediterranean basin: evidence from refraction and sedimentary studies in Israel and in Sinai. Sediment. Geol., 23:19-36.

Gvirtzman, G., 1970. The Saqiye Group (late Eocene to early Pleistocene) in the Coastal Plain and HaShephela regions, Israel. Geol. Surv. Isr. Bull., $51: 1-180$

Hall, J.K., 1980. Bathymetric chart of the Southeastern Mediterranean Sea. Geol. Surv. Isr.-Mar. Geol. Div., Rep. MG/13/80.

Hall, J.K., Udintsev, G.B., and Odinikov, Y.Y., 1994. The bottom relief of the Levantine Sea. In Krasheninnikov, V.A., and Hall, J.K., (Eds)., Geologic Structure of the Northeastern Mediterranean: Jerusalem (Historical Productions-Hall Ltd.), 5-32.

Hirsch, F., 1984. The Arabian sub-plate during the Mesozoic. In Dixon, J.E., and Robertson, A.H.F. (Eds.), Geological Evolution of the Eastern Mediterranean. Geol. Soc. Spec. Publ. London, 17:217-224.
Hirsch, F., Flexer, A., Rosenfeld, A., and Yellin-Dror, A., 1995. Palinspastic and crustal studies of the Eastern Mediterranean. J. Pet. Geol., 18:149170.

Hirsch, F., and Picard, L., 1988. The Jurassic facies in the Levant. J. Pet. Geol., 11:277-307.

Horowitz, A., 1979. The Quaternary of Israel: New York (Academic Press).

Hsü, K.J., 1992. Tectonic facies concept applied to interpret the geology of Cyprus. Rapp. Proc. Verb. Comm. Int. Expl. Mer Mediterr, 33:90.

Kempler, D., 1994. An outline of north-Eastern Mediterranean tectonics in view of Cruise 5 of the Akademik Nikolaj Strakhov. In Krasheninnikov, V.A., and Hall, J.K. (Eds.), Geological Structure of the North-Eastern Mediterranean (Cruise 5 of the Research Vessel Akademik Nikolaj Strakhov), 277-293.

Kempler, D., and Ben-Avraham, Z., 1987. The tectonic evolution of the Cyprean Arc. Ann. Tecton., 1:58-71.

Kogan, L.I., and Stenin, A.M., 1994. Multichannel MOV-OGT (CDP) seismic profiling during cruise 5 of R/V Akademik Nikolaj Strakhov (preliminary results). In Krasheninnikov, V.A., and Hall, J.K. (Eds.), Geologic Structure of the Northeastern Mediterranean: Jerusalem (Historical Productions-Hall Ltd.), 99-112.

Krasheninnikov, V.A., and Hall, J.K., 1994. Geological Structure of the Northeastern Mediterranean (Cruise 5 of Ctr Research Vessel) "Acdemik Nikolas Strakhov": Jerusalem (Historical Productions-Hall Ltd.). [17-2695]

Krasheninnikov, V.A., Udintsev, G.B., Mouraviov, V., and Hall, J.K., 1994. Geological structure of the Eratosthenes Seamount. In Krasheninnikov, V.A., and Hall, J.K. (Eds.), Geological Structure of the Northeastern Mediterranean (Cruise 5 of the Research Vessel Akademik Nokolaj Strakhov): Jerusalem (Historical Productions-Hall Ltd.), 113-130.

Lapierre, H., 1975. Les formations sedimentaires et eruptives des nappes de Mamonia et leur relation avec le massif du Troodos (Chypre occidentale). Mem. Soc. Geol. Fr. 123

Laws, E.D., and Wilson, M., 1996. Neotethyan rifting and magmatism in the Middle East. IGCP Project 369, 3rd Ann. Meeting, Abstr., 29.

Limonov, A.F., Woodside, J.M., and Ivanov, M.K. (Eds.), 1994. Mud Volcanism in the Mediterranean and Black Seas and Shallow Structure of the Eratosthenes Seamount. Initial Results of the Geological and Geophysical Investigations during the Third "Training-through-Research" Cruise of the R/V Gelendzhik (June-July 1993). UNESCO Rep. Mar. Sci., 64.

Makris, J., Ben-Avraham, Z., Behle, A., Ginzburg, A., Gieze, P., Steinmetz, L., Whitmarsh, R.B., and Eleftheriou, S., 1983. Seismic refraction profiles between Cyprus and Israel and their interpretation. Geophys. J. R. Astron. Soc., 75:575-591.

Makris, J., and Wang, J., 1994. Bouguer gravity anomalies of the Eastern Mediterranean Sea. In Krasheninnikov, V.A., and Hall, J.K. (Eds.), Geological Structure of the North-Eastern Mediterranean: Jerusalem (Historical Productions-Hall Ltd.), 87-98.

Makris, J., Wang, J., Odintsov, S.D., and Udintsev, G.B., 1994. The magnetic field of the Eastern Mediterranean Sea. In Krasheninnikov, V.A., and Hall, J.K. (Eds.), Geological Structure of the North-Eastern Mediterranean: Jerusalem (Historical Productions-Hall Ltd.), 75-85.

Malovitsky, Y.P., Emelyanov, E.M., Kazakov, O.V., Moskalenko, V.N., Osipov, G.V., Shimkus, K.M., and Chumakov, I.S., 1975. Geological structure of the Mediterranean sea floor (based on geological and geophysical data). Mar. Geol., 18:231-261.

Malpas, J., Moores, E.M., Panayiotou, A., and Xenophontos, C. (Eds.), 1990. Ophiolites: Oceanic Crustal Analogues: Nicosia, Cyprus (Geol. Surv. Dep., Minist. Agric. Nat. Resour.).

Malpas, J., Xenophontos, C., and Williams, D., 1992. The Ayia Varvara Formation of SW Cyprus: a product of complex collisional tectonics. Tectonophysics, 212:193-211.

Mart, Y., 1979. The Eratosthenes seamount and some structural outlines of the southeastern Mediterranean. Rapp. Proc. Verb. Comm. Int. Expl. Mer Mediterr., 25/26:113.

, 1987. Superpositional tectonic patterns along the continental margin of the southeastern Mediterranean: a review. Tectonophysics, 140:213-232.

, 1991. Some Cretaceous and early Tertiary structures along the distal continental margin of the southeastern Mediterranean. Isr. J. Earth Sci., 40:77-90.

1994. The tectonic origin of the Senonian marine basin underneath the southeastern Mediterranean Sea. Tectonophysics, 234:5-18. 
Mart, Y., Robertson, A.H.F., Woodside, J., and ODP Leg 160 Shipboard Science Party, 1997. Cretaceous tectonic setting of Eratosthenes Seamount in the eastern Mediterranean Neotethys: initial results of ODP Leg 160. C.R. Acad. Sci. Ser. 2a, 324:127-134.

McCoy, F., and Mart, Y., 1988. Eratosthenes Seamount: a mid-ocean dipstick recording the late Tertiary and Quaternary marine geological history of the eastern Mediterranean. Rapp. Proc. Verb. Comm. Int. Expl. Mer Mediterr., 31:81.

McKenzie, D.P., 1970. Plate tectonics of the Mediterranean region. Nature, 226:239.

Moores, E.M., Robinson, P.T., Malpas, J., and Xenophontos, C., 1984. Model for the origin of the Troodos massif, Cyprus, and other Mideast ophiolites. Geology, 12:223-226.

Moores, E.M., and Vine, F.J., 1971. The Troodos Massif, Cyprus and other ophiolites as oceanic crust: evaluation and implications. Phil. Trans. R. Soc. London A, 268:422-466.

Morris, A., 1995. A review of palaeomagnetic research in the Troodos ophiolite, Cyprus. In Morris, A., and Tarling, D.H. (Eds.), Palaeomagnetism and Tectonics of the Mediterranean Region. Geol. Soc. Spec. Publ. London, 105:311-324.

Murat, A., 1984. Sequences et paleoenvironments marins quaternaires une marge active: 1'arc hellenique oriental [These Doct. III Cycle]. Univ. Perpignan.

Murat, A., and Got, H., 1987. Middle and late Quaternary depositional sequences and cycles in the eastern Mediterranean. Sedimentology, 34:885-899.

Musaka, S., and Ludden, J.N., 1987. Uranium-lead ages of plagiogranites from the Troodos ophiolite, Cyprus, and their tectonic significance. Geology, 15:825-828.

Neev, D., Almagor, G., Arad, A., Ginzburg, A., and Hall, J.K., 1976. The geology of the Southeastern Mediterranean. Geol. Surv. Isr. Bull., 68:151.

Neev, D., Greenfield, L.L., and Hall, J.K., 1985. Slice tectonics in the eastern Mediterranean basin. In Stanley, D.J., and Wezel, F.C. (Eds.), Geological Evolution of the Mediterranean Basin: New York (Springer-Verlag), 249-269.

North, R.G., 1974. Seismic slip rates in the Mediterranean and Middle East. Nature, 252:560-563.

Pearce, J.A., Lippard, S.J., and Roberts, S., 1984. Characteristics and tectonic significance of supra-subduction zone ophiolites. In Kokelaar, B.P., and Howells, M.F. (Eds.), Marginal Basin Geology. Geol. Soc. Spec. Publ. London, 16:74-94.

Picard, L., 1943. Structure and evolution of Palestine. Bull. Geol. Dep., Hebrew Univ., Jerusalem, 4:1-134.

Poole, A.J., Shimmield, G.B., and Robertson, A.H.F., 1990. Late Quaternary uplift of the Troodos ophiolite, Cyprus: uranium series dating of Pleistocene coral. Geology, 18:894-897.

Robertson, A.H.F., 1990. Tectonic evolution of Cyprus. In Malpas, J., Moores, E.M., Panayiotou, A., and Xenophontos, C. (Eds.), Ophiolites: Oceanic Crustal Analogues. Proc. Symp. "Troodos 1987," Nicosia, Cyprus (Geol. Surv. Dep., Minist. Agric. Nat. Resour.), 235-250.

, 1992. Drilling the Eratosthenes Seamount: Mediterranean collision tectonics and Plio-Quaternary palaeo-oceanography in the light of the geology of Cyprus. Rapp. Comm. Mer Medit., 33:393.

Robertson, A.H.F., Clift, P.D., Degnan, P., and Jones, G., 1991. Palaeogeographic and palaeotectonic evolution of the Eastern Mediterranean Neotethys. Palaeogeogr., Palaeoclimatol., Palaeoecol., 87:289-344.

Robertson, A.H.F., and Dixon, J.E., 1984. Introduction. In Dixon, J.E., and Robertson, A.H.F. (Eds.), The Geological Evolution of the Eastern Mediterranean. Geol. Soc. Spec. Publ. London, 17:1-74.

Robertson, A.H.F., Emeis, K.-C., Richter, C., Blanc-Valleron, M.-M., Bouloubassi, I., Brumsack, H.-J., Cramp, A., De Lange, G.J., Di Stefano, E., Flecker, R., Frankel, E., Howell, M.W., Janecek, T.R., Jurado-Rodriguez, M.-J., Kemp, A.E.S., Koizumi, I., Kopf, A., Major, C.O., Mart, Y., Pribnow, D.F.C., Rabaute, A., Roberts, A.P., Rullkötter, J.H., Sakamoto, T., Spezzaferri, S., Staerker, T.S., Stoner, J.S., Whiting, B.M., and Woodside, J.M., 1995a. Evidence of collisional processes associated with ophiolite obduction in the eastern Mediterranean: results from Ocean Drilling Program Leg 160. GSA Today, 5:213-221.
Robertson, A.H.F., Kidd, R.B., Ivanov, M.K., Limonov, A.F., Woodside, J.M., Galindo-Zaldivar, J., and Nieto, L., 1994. Probing continental collision in the Mediterranean Sea. Eos, 75:233.

Robertson, A.H.F., Kidd, R.B., Ivanov, M.K., Limonov, A.F., Woodside, J.M., Galindo-Zaldivar, J., and Nieto, L., 1995b. Eratosthenes Seamount, easternmost Mediterranean: evidence of active collapse and underthrusting beneath the Cyprus active margin. Terra Nova, 7:254-264.

Robertson, A.H.F., and Woodcock, N.H., 1980. Tectonic setting of the Troodos massif in the East Mediterranean. In Malpas, J., Moores, E.M., Panayiotou, A., and Xenophontos, C. (Eds.), Ophiolites: Oceanic Crustal Analogues. Proc. Symp. "Troodos 1987," Nicosia, Cyprus (Geol. Surv. Dep., Minist. Agric. Nat. Resour.), 36-49.

Robertson, A.H.F., and Xenophontos, C., 1994. Development of concepts concerning the Troodos ophiolite and adjacent units in Cyprus. In Prichard, H.M., Alabaster, T., Harris, N.B. and Neary, C.R. (Eds), Magmatic Processes and Plate Tectonics. Geol. Soc. Spec. Publ. London, 76:85120.

Ross, D.A., and Uchupi, E., 1977. Structure and sedimentary history of southeastern Mediterranean Sea-Nile Cone. AAPG Bull., 61:872-902.

Rotstein, Y., and Kafka, A.L., 1982. Seismotectonics of the Cyprean Arc, Eastern Mediterranean Region: subduction, collision and arc jumping. $J$. Geophys. Res., 87:7694-7707.

Ryan, W.B.F., Hsü, K.J., et al., 1973. Init. Repts. DSDP, 13 (Pts. 1 and 2): Washington (U.S. Govt. Printing Office).

Ryan, W.B.F., Stanley, D.J., Hersey, J.B., Fahlquist, D.A., and Allan, T.D., 1970. The tectonics and geology of the Mediterranean Sea. In Maxwell, A.E. (Ed.), The Sea (Vol. 4), 387-492.

Sage, L., Letouzey, J., and Montadert, L., 1988. Geological structure of the deep eastern Mediterranean Sea (east of 250E). Rapp. Comm. Int. Mer Mediterr., 31:103. (Abstract)

Searle, M.P., and Malpas, J., 1982. Petrochemistry and origin of sub-ophiolitic metamorphic rocks in the Oman Mountains. J. Geol. Soc. London, 139:235-248.

Sengör, A.M.C., Yilmaz, Y., and Süngürlü, O., 1984. Tectonics of the Mediterranean Cimmerides: nature and evolution of the western termination of the Paleo-Tethys. In Dixon, J.E., and Robertson, A.H.F. (Eds.), The Geological Evolution of the Eastern Mediterranean. Geol. Soc. Spec. Publ. London, 17:77-112.

Smith, A.G., 1971. Alpine deformation and the oceanic areas of the Tethys, Mediterranean, and Atlantic. Geol. Soc. Am. Bull., 82:2039-2070.

Steinitz, G., Gvirtzman, G., and Lang, B., 1982. Evaluation of K-Ar ages of the Asher volcanics: current research 1982. Geol. Surv. Isr., 34-38.

Swarbrick, R.E., and Robertson, A.H.F., 1980. Revised stratigraphy of the Mesozoic rocks of southern Cyprus. Geol. Mag., 117:547-563.

Tanner, S.J., and Williams, C.A., 1984. A detailed survey near mount Eratosthenes, Eastern Mediterranean. Mar. Geophys. Res., 6:205-222.

Varnavas, S.P., Papaioannou, J., and Catani, J., 1988. A hydrothermal manganese deposit from the Eratosthenes Seamount, eastern Mediterranean Sea. Mar. Geol., 81:205-214.

Weissbrod, T., 1981. The Paleozoic of Israel and adjacent countries. Geol. Surv. Isr. Rep., MP 600/81. (in Hebrew with English abstr.)

Whitechurch, H., Juteau, T., and Montigny, R., 1984. Role of the Eastern Mediterranean ophiolites (Turkey, Syria, Cyprus) in the history of the Neo-Tethys. In Dixon, J.E., and Robertson, A.H.F. (Eds.), The Geological Evolution of the Eastern Mediterranean. Geol. Soc. Spec. Publ. London, 17:301-318.

Woodside, J.M., 1977. Tectonic elements and crust of the eastern Mediterranean Sea. Mar. Geophys. Res., 3:317-354.

Woodside, J.M., and Williams, S.A., 1977. Geophysical data report of the Eastern Mediterranean Sea: RRS Shackleton cruises 3/72, 5/72, 1/74. Dep. Geodesy. and Geophysics, Cambridge Univ., U.K.

\footnotetext{
Date of initial receipt: 17 February 1997

Date of acceptance: 21 October 1997

Ms 160SR-034
} 